\title{
A CHURCH IN ENTROPY: CATHOLIC ADELAIDE, 1868-1873
}

\author{
Brian Condon
}

The priest walked the hundred yards or so from the Bishop's House to the convent. He announced himself, and asked to see the Mother Prioress. He was held at the door. Eventually it was the Sub-Prioress who appeared at the door, and then only to tell him that the Mother Prioress was still not willing to see him. His warning that he now felt compelled to report to the Holy See the continued insubordination of the sisters attracted the rejoinder that he might please himself what he did.

He retraced his steps and wrote his report ${ }^{1}$ to Alessandro Cardinal Barnabò, Prefect of the Holy See's Sacra Congregatio de Propaganda Fide (in more contemporary terms, the Chief Executive Officer of the Department of Foreign Missions), foregrounding his fear of anarchy in the convent, but stressing also the iniquities of the local cabal still intriguing against him.

The priest was Christopher Augustine Reynolds. Only six months before, he had been officially confirmed for the first time as Administrator of the diocese of Adelaide pending the appointment of a bishop to succeed Lawrence Bonaventure Sheil OSF, who had died nine months before, on 1 March 1872 ('passed to a better life,' as Rome put it, with no doubt unconscious irony).

'[O]fficially confirmed for the first time...' This seeming over-fastidiousness about the sureness of Reynolds's authority is in fact a totally accurate representation of the uncertainty and dislocation of the Adelaide diocese over the preceding several years: unresolved tensions between power of the de iure and de facto types. So patent was the resulting vacuum of authority that by August of the same year Reynolds had himself received Rome's nomination as the new Bishop of Adelaide - in record time, under the circumstances.

ADELAIDE DIOCESAN affairs had achieved wide and unwelcome notoriety. Even non-Anglo-Celt dioceses on the fringe of central church concerns were beginning to hear of them-let alone Rome, the decision centre of very active and diverse strivings of the mid-nineteenth century to produce a 'universal church.'

1. Condon 1994b: Reynolds to Barnabò, 3 Jan. 1873. 
The Holy See's acknowledged central power to decide was often invoked, never more so than when the cry of scandal was raised. Under that rubric Rome had recently been the target of much information about Adelaide which increasingly used that very term, so feared by conservative church administrators: 'scandal,' horribile dictu. Worst of all, this was public scandal, scandal available to the general public and therefore open to unfriendly construction and lurid exaggeration by Catholic, heretic, and heathen alike-all equally uncontrolled and uncontrollable. A fortiori, and most important of all, lay people could not be so easily brought under direct sanctions as clergy and religious were, since public scandal was not containable within the church's Chinese walls of discipline: the virtues of prudence, charity, etc. ${ }^{2}$

What had happened to warrant the heavy attribution of 'scandal' to the Adelaide diocese? What did it mean? What had caused this well-nigh total rejection of authority? And further, what could be done to retrieve an obviously depressed situation? And above all, why?

The best-known event, then as now, was the excommunication of Mary MacKillop. Less well known is that an investigation into the affairs of the Adelaide diocese had - rather extraordinarily — been ordered by Rome before the death of Bishop Sheil, prompted by receipt of a letter from influential Adelaide laity. ${ }^{3}$ The two Bishops who comprised the 'Apostolic Commission' (Matthew Quinn of Bathurst and Daniel Murphy of Hobart) eventually began the investigation in Adelaide on 6 June 1872. All of these major events need to be put into the larger context: an organization in entropy.

WE MAY ENTER upon an explanation by continuing with the assertions of Reynolds's letter. An edge of hysteria creeps into his tone as he observes:

The convent is a scene of scandal and riot. Were it in the power of the inmates or if she had the talent I fear we would have Port Royal scenes all over again.

A little overblown, to say the least: there were in all only seven of these Dominican sisters, brought out from Ireland three years earlier by the late Bishop Sheil, and they were virtually all young and inexperienced, rather than hardened bluestockings. $^{4}$

2. For an earlier example, see my edition of the diary of James Alipius Goold, first Bishop and Archbishop of Melbourne: Apr. and May 1862, the Barry scandal. Better still, read Margaret Pawsey's Demon of Discord.

3. Condon 1994a: Adelaide laity to Barnabò, 10 Dec. 1871.

4. Condon 1994b: Murray to Cullen, 30 Oct. 1873: 'they were geese.' 
'Port-Royal' is the eponym which stands for all cases of egregious misrule among congregations of female religious - at least in the eyes of episcopal superiors, who recognize none of the robust intellectual independence, which is instead totally screened out by that binocular filter unique to bishops: one eye for hierarchy, the other for patriarchy.

The real source of Reynolds's anxiety was that of virtually any bishop of the time: faction, a word which recurs constantly and shudderingly in the episcopal correspondence of the nineteenth century. (And before and since, no doubt!) And Adelaide had faction aplenty!

We should note here that these Dominican sisters had been on the side of the losing faction, and Reynolds's plan did not include giving aid and comfort to the enemy.

At stake, as we shall see, was a conception of 'nun-ness' that was in flux under new conditions. An episcopal view of their place and style that would have been endorsed with acclamation by any nineteenth-century bishop comes from Bishop J.T. Hynes to his nephew and protégé J.A. Goold:

How much I wish you had a choice community of nuns. They would be the greatest comfort to you individually and a blessing to the Catholics of Victoria. Before I had dealings with them I had no conception of the extraordinary heroism they are capable of shewing, and so unselfish, so inspiring, so dutifully respectful and obedient to the slightest wish of their Bishop. These Irish nuns (I speak without reference to any particular Order) are prepared to go anywhere, perfectly undismayed by difficulties. They never ask a question of a Bishop whom they trust, as to how they are to be maintained, whether the climate is good or bad? They seem anxious only to know how many children of poor and rich are to be educated and saved. To be sure, a prudent and generous Bishop will not neglect making such arrangements for their reception as his means will allow, and I know that you are both one and the other. ${ }^{5}$

Another part of the official role model propounded by male clergy offered women two categories: 'saintly virgins who always hated sex, and repentant whores who learnt through bitter experience to hate it. ${ }^{6}$ Where bishops encountered inconvenient independence in women they were quick to call it 'want of respect for authority,' and diagnose a breakdown in discipline. The next step was to merely hint at sexual scandal-and one had thereby provided ample warrant for total repression. This was the fate of the Dominican sisters. Having attached themselves to the losing faction, and having given hospitality in their convent to

5. Condon 1993a: Hynes to Goold, 7 July 1853.

6. Stanford 1991, p. 26. 
priest members of it, they were rewarded by being represented as a sybaritic and licentious rabble.

So much so, indeed, that when James Murray was passing on rumours in a private letter to his mentor, Cardinal Cullen in Dublin, he painted a sorry enough picture - but when he came to the allegation that a nun had spent the night more than once with a Franciscan, Charles Horan, he appears to have suffered a fit of the vapours, because he broke into Italian to report it. ${ }^{7}$ We will return to this analysis later. To set the grounds for a broader explanation, however, we must go back a little in time.

THE FOUNDATION of Adelaide as a diocese was ill-judged and premature. It was originally planned, along with that of the See of Van Diemen's Land (based in Hobart), to resolve the geographical impossibility of providing episcopal supervision only from Sydney. It was also driven by the constant wish to get in ahead of the Anglicans, and eventually fuelled by the need to make a play (successfully) for the Leigh Bequest, originally intended to endow an Anglican diocese of South Australia, whose donor William Leigh had recently converted to Catholicism. Even the winning of the bequest, however, was not sufficient to make up for the litany of deficiencies of the struggling diocese, which was to know nothing but hard times for the whole of the century.

As Vicar-General of the whole of Australia, Francis Murphy knew full well that Adelaide in 1843 was 'scarcely able to support poor Mr Benson' (the one priest stationed there). Rome had requested, however, and he accepted the bishopric as under obedience; he called it 'one of the most painful sacrifices that I have been ever compelled as yet to offer,' one of the complications being that 'my poor sister is inconsolable at the very thought of my being fixed here [in Australia] for life. ${ }^{8}$ Murphy rounded off his point by choosing as his motto Non recuso laborem (I shall not shrink from the toil).

Attracting a clerical staff was always to be a problem for Adelaide. Even on those few occasions when the bishop had qualified confidence that funds seemed likely to be available to support priests, it was difficult to attract them to a mission whose poverty was well advertised in Europe and especially in Ireland, whence most of the priests had eventually to come; virtually none of the priests had any private means, and even the most unworldly usually needed to be assured of sufficient surplus to support a relative 'at home.' The founding Bishop of Adelaide, the revered Francis Murphy, and his friend and successor Geoghegan were themselves both cases in point, as was Goold of Melbourne.

7. Condon 1994b: Murray to Cullen, 30 Oct. 1873.

8. Condon 1994b: F.M. to Geoghegan, 4 May 1843.

9. Condon 1993a: Hynes to Goold, 18 Jan. 1849, 27 Sept. 1851; 1994b: Murphy to Geoghegan, 15 Mar. 1842. 
The poverty of dioceses and the compelling need for more priests conspired often enough to induce an Australian bishop to suspend normal prudent hesitations and take virtually any candidate who offered and was not positively known to be under ecclesiastical censure. European bishops, sad to relate, were not always scrupulous in observing their duty to protect their Australian brothers, and many notably imperfect subjects were foisted upon antipodean dioceses. ${ }^{10}$

With at least its fair share of clerical sins, vices, and peccadilloes, Adelaide acquired, perhaps more than most, an unfortunate reputation for unbridled intemperance, one widely believed even in Rome. ${ }^{11}$ One anecdote from 1850 comes from a priest serving in Adelaide at the time. It conveys a roistering tone which was to be reinforced under Sheil and was to haunt Reynolds even in the eighties:

Coyle...was...very clever, but unfortunately at the same time very drunken..... One gentleman told me that he had left six bottles of wine under the bed of a room in which he had let Coyle sleep and he found them all dead men in the morning. ${ }^{12}$

But while Bishop Murphy may have experienced the worst of what were never to be good economic times, he nonetheless always enjoyed the respect and affection of his priests and his laity - and even of tout Adelaide: high society, such as it was. And he was always in uncontested command. One of the elements which contributed powerfully to this was that Murphy could in no sense be called an absentee landlord, as his two immediate successors Geoghegan and Sheil could all too easily be dubbed.

With modern organizations, not excluding universities, abounding in Mission Statements, no one should feel any shock that the church had to support its ideological and spiritual roles with organization in the secular world. Hierarchy and bureaucracy came naturally, but we should add the observation that bureaucracies are rule-governed systems in which law and rationality should play a powerful part.

At this point it may be as well to emphasize the secularity of this account by turning to classic organization theory to explain aspects of the functioning of the Catholic Church. Certainly the church was, and is, a giant bureaucracy headquartered in Rome, with all the ramifications of that. A chagrined Archbishop Polding made a very modern complaint to his Melbourne colleague Goold in 1865 , lamenting Rome's failure to discipline summarily members of a faction gone to Rome to make their own representations about his administration:

10. E.g., Condon 1994b: Polding to Cardinal Prefect, 14 Apr. 1861; Reynolds to Vicar-General, 7 Mar. 1880.

11. Condon 1994b: Reynolds to Vicar-General, 4 June 1880.

12. Condon 1994b: Caldwell to Smyth, 24 Jan. 1870. 
The solution to the problem, I fancy, is to be found in the shamefully easy access to the printing office of Propaganda, and the general leakiness of the venerable Institution.... With all due respect, they do manage things strangely at Headquarters. ${ }^{13}$

Many of the elements of so-called classical organization theory, usually identified with Max Weber and Henri Fayol, figure here negatively. Polding's complaint is that the proper operation of hierarchy and bureaucracy are being trammelled by intrigue, that communication is indifferent or corrupted, that there is interference in the central management processes of planning, organizing, and controlling. Polding is here stressing the dysfunctional negativities of the relationship with Rome. Speaking to a brother bishop, he expects a sympathetic ear to this complaint about the abatement of the episcopal power. Not for nothing is a bishop called 'My Lord.' All aspects of governance inside the diocese are in his hands. Yet he cannot legally be a despot and his subordination to Rome as the apex of the hierarchical system is essentially to guarantee the proper conduct of affairs and the rights of his subjects under Canon Law. Polding's complaints-and these were typical, rather than peculiar to him-merely remind us that a symbiosis has its costs.

None of this, of course, should be taken as an attempt to put some sort of liberal-democratic gloss onto an obviously monarchical organization. Rather it is to point out that it was essentially a constitutional monarchy, with some concern for what we might now call the legal-rational mediation of power into authority. We should remember as well that the one period of under two decades saw Rome assert its ultramontanist primacy with the proclamation of the dogmas of the Immaculate Conception (1854) and of Papal Infallibility (1870), and the publication of the encyclical Quanta Cura and its attached Syllabus of Errors (1864), in which secular liberalism was ringingly condemned.

Like virtually all the bishops of the period, too, Polding was no liberal democrat: church affairs were the bishop's responsibility, even the temporal affairs, and the laity had no role in their management: 'Lay influence has prevailed, and lay influence must be crushed. ${ }^{14}$ To illustrate Polding's preoccupations, however, take his account of the St. Vincent's Hospital affair, which had a sensational press coverage quoting clerical incompetence and dereliction of duty, apostasy, proselytism, and sectarianism. Polding's general summary of the affair to another bishop, however, chooses to concentrate heavily on its providing 'one of the most convincing instances of the folly of lay persons, however good, mixing in Church matters.' 15

13. Condon 1994b: Polding to Goold, 26 Aug. 1865.

14. Condon 1994b: Polding to Geoghegan. Undated, but probably early 1860.

15. Condon 1994b: Polding to a bishop, 20 June 1859. 
Episcopal consecration puts a bishop at the top of the hierarchy in his own diocese. It also sets him very much apart. Bishop Hynes, Goold's uncle, met Geoghegan in Europe and took an instant dislike to him. He wrote to Goold to caution him against Geoghegan, whom he characterized as vain, silly, and jealous. $\mathrm{He}$ also passed on to Goold a first principle of episcopal governance:

Never lay yourself under the obligation for the execution or discharge of any duty of importance, and take counsel from others but rarely, and then in small quantities written or otherwise, which you can do yourself-Matters of moment which you need not communicate to others, keep to yourself. ${ }^{16}$

Whether or not he took it from Hynes, Goold was a notable practitioner of precisely this style - and this prescription for the solitary life! Even Goold's private diary is hardly a personal document. It is more a record of devotional practices observed and of faithfulness to the ordered life of duty. Goold, though, does appear to have taken from Hynes one other piece of advice: 'Don't fret yourself about Geoghegan, but take your time and quietly get rid of him. ${ }^{17}$ On the death of Francis Murphy some six years later, Goold successfully nominated Geoghegan for the vacant See of Adelaide.

The imperious Geoghegan had long sought a bishop's mitre, despite his many protestations to the contrary. Once consecrated for Adelaide, he appears to have made immediate plans to have himself translated to a more salubrious Australian diocese. The ubiquitous 'health' was as usual much advanced. He was eventually translated to the newly created diocese of Goulburn, but died in Dublin before taking possession of the See.

Several of his decisions were to leave a mark on the diocese well beyond his short residence in it (of little more than eighteen months). None was more productive of discord than his campaign for government support for denominational schools, orchestrated as a flurry of petitions to Parliament, to which were joined constant commands to priests to establish and support Catholic schools in their districts. Geoghegan's Pastoral Letter of 1860 was a document of some eloquence (half of it is quoted directly from a Pastoral Letter issued in Sydney a short while before by Archbishop Polding). It is a locus classicus of the State Aid arguments of nearly a century later.

The Catholic Church in the eastern colonies had benefited substantially from a system of government funding to build, equip, and staff denominational schools. In South Australia a similar provision had been only briefly in force, and had been replaced from 1851 by a system designed to establish government schools. These were to be secular, understood at the time as non-denominational Christian, since

16. Condon 1993a: Hynes to Goold, 11 Nov. 1849. Italics in the original.

17. Condon 1993a: 5 Nov. 1852. 
the Bible was read in them. Many of these schools were de facto denominational, Catholic ones among them.

With no means to do otherwise, Murphy had tolerated those schools. ${ }^{18}$ Not so Geoghegan: the Central Board schools were condemned; only schools that were totally Catholic would suffice. The command to 'go it alone' imposed a heavy financial burden on the Catholics, still a notably poor section of the population, and not even every priest thought that 'giving up the grant' was necessary. Objections were muted, and a sectarian storm diverted the passions. Geoghegan was soon out of the diocese on a recruiting mission to Europe. He left in February 1862, and died in Dublin on 8 May 1864.

Another of his legacies was the division of authority in the diocese. The priest who held the title of Vicar-General was Michael Ryan of Kapunda, Murphy's companion at the foundation of the diocese. In his 1863 Report to the Holy See, Geoghegan dismissed Ryan as

gouty, nervous and heavy, with strong tendencies to apoplexy.... He...holds the authority of Vicar-General, though the actual management of ecclesiastical affairs is conducted, of course subordinately, by the Rev. John Smyth, residing in the City. 19

Geoghegan's characterization of Smyth's powers as subordinate was for form's sake merely. Whatever Smyth's ability, though (and he was already marked out for promotion to bishop), he was in a false position, and had to tread delicately.

To internal dissent over the push for separate Catholic schools and to the somewhat ambiguous nature of Smyth's authority, Geoghegan added another burden - that of counselling a rigorist attitude to discipline:

The chief point is never to dispense the strict letter of the law for any sympathy whatever-one precedent of feeling over rule will be the small end of the wedge. Let feeling have another arena. ${ }^{20}$

Geoghegan died in Dublin, as we have seen, on 8 May 1864. His mantle fell to a fellow Franciscan, Lawrence Bonaventure Sheil, who had also laboured long in Melbourne with Goold. He too, like Geoghegan, had professed to be uninterested in promotion:

18. Thomas 1989: Chap. Two gives an extended account.

19. Condon 1994b: Report to the Holy See, late 1860.

20. Condon 1994b: Geoghegan to Smyth, 25 Sept. 1862. Italics in original. 
...tho I am his [the Bishop's] great favourite, I have no ambition to travel with Bishops; he treats me most affectionately, and I keep in my position. $^{21}$

Sheil arrived in Adelaide to take possession of his See on 14 September 1866-a new bishop, four years and seven months after Geoghegan's last departure from the diocese. Seven months later (26 April 1867), Sheil left for Europe to recruit priests, and was absent for a year and seven months. Ten months later (October 1869), he was off to Europe again, this time for the First Vatican Council, and returned fifteen months later, already mentally and physically impaired. He died a year later, on 1 March 1872.

In the fifteen-and-a-half years from the death of Murphy to the consecration of Sheil's successor, Christopher Augustine Reynolds (1 November 1873), Adelaide had been without a bishop in residence for eleven years and two months-about seventy-five percent of the period. The raw arithmetic is telling enough, but what was critical was the length of most of the periods involved, the uncertainty about the length of most absences, and the consequent and understandable reluctance of a temporary deputy to take bold action. In not one case could any Vicar-General have felt so empowered, and one who fell into the job and felt impelled to decisive corrective action (Russell) was rewarded for his pains by being hounded out of the diocese by Sheil. ${ }^{22}$

The bishop also repeated the cardinal management error of subjecting Adelaide once more to divided control. To himself and his canonical Vicar-General, the very competent and experienced Smyth, he added the Rev. Julian Tenison Woods to form 'a kind of triumvirate' of decision-making, as an old hand (the Jesuit Fr. Joseph Tappeiner) reported in 1872 in a confidential report commissioned by the Cardinal Prefect of Propaganda Fide-with all due process: Cardinal to Father General of the Jesuits, to Austrian Jesuit Provincial Superior, to Tappeiner.

The violation of central considerations of good management structure was bad enough, but these two good and able men could not have been more different in their temperament and style. As Tappeiner succinctly puts it:

The Vicar-General went along well-trodden ways, prudently and cautiously; his motto was 'Change only with the warrant of tradition' [ $\mathrm{Nil}$ innovetur nisi quod traditum est]. The Rev. Woods, impatient of human prudence, tried to rush into the fray without deliberation wherever there was any good to be done, his motto being 'Behold I make all things new.'

21. Condon 1994b: Sheil to Reville, 7 Jan. 1856.

22. Condon 1994a: Sheil to Russell, 17 July 1871, for the opening shot.

23. Condon 1994a: Tappeiner to Father General, 30 Oct. 1872. 
Tappeiner attempts to modify this characterization with the heroic statistical conclusion: 'Since they both sought good, management was possible by striking a mean, one might say. ${ }^{24}$

But striking a mean was foreign to the zealous and impulsive Woods, who treated disagreement with his proposals not only as a cross-as ordinary mortals might-but also as a sure sign of divine approval. ${ }^{25}$ A most irritating characteristic. Thorpe sums it up in an aphoristic sally: '...nothing had an uglier look than reason when it was not on his side. ${ }^{26}$

Some of this no doubt was the product of Woods's decided mystical bent. He had confided to Tappeiner that he had himself had many visions, and thought them to be infallibly from God and a special personal gift. Tappeiner commented:

He is so certain in his own opinion that when it is suggested he read approved ascetical authors who treat of these matters he refuses, because 'they would only confuse his mind and introduce doubts, and he wishes to be led by God alone.'

'A very good principle,' concludes Tappeiner dryly, 'but dangerous, since one rarely finds God directly guiding people thus. ${ }^{27}$

The eclectically educated Woods was coruscatingly talented, even if not always in the appropriate areas. Geoghegan, for instance, had rather cattily reminded Woods of his defective theological training - as an aside, while pursuing a separate disciplinary point. ${ }^{28}$

Woods had become the spiritual director of Mary MacKillop five years before. He responded enthusiastically to her wish to join a religious Order. When no existing Order in Australia met her stipulation of abject poverty he at first thought of directing her to a French Order he had encountered in the Auvergne some twelve years before, but they eventually settled on the project of jointly founding a new Australian religious Order.

Always hyperactive, Woods had taken himself off to Melbourne for the consecration of Bishop Sheil on 15 August 1866. His zeal and charm won him the new Bishop's favour, and vast advancement: he was to leave Penola for Adelaide as the Bishop's secretary and personal chaplain, Director-General of Catholic Education and Inspector of Schools. And the Bishop approved the foundation of the new Order: the Institute of the Sisters of St. Joseph of the Sacred Heart.

24. Condon 1994a: Tappeiner to Father General, 30 Oct. 1872.

25. Foale 1989, p. 19.

26. Thorpe 1957, p. 72.

27. Condon 1994a: Tappeiner to Father General, 30 Oct. 1872.

28. Condon 1994b: Woods to Geoghegan, 23 Apr. 1863. 
Woods's titles had little warrant in management of education or in actual teaching in schools, of which he had had only an unhappy few weeks' experience. Rather, they derived from the great acceptability to the Bishop of the project of founding in South Australia a new Australian religious Order dedicated to poverty and the Catholic education of the children of the Catholic poor. The new Bishop's ready acceptance of the notion of the Institute is easily enough explained. Committed to continuing his predecessor's policy in Catholic education, he saw only a band of dedicated workers whose mission it was to remove his greatest problem: the education of the poor, the vast majority of his flock.

The Bishop's Vicar-General, Fr. John Smyth, had known Woods for ten years and had come to dread his enthusiasms as 'fires of straw,' for which the proper treatment was 'deluges of cold water. ${ }^{29}$ Not even Smyth, however, could have foreseen the conflagrations soon to be ignited by the firebrand Woods.

Three days before the Bishop left for Europe (26 April 1867) he publicly confirmed Woods as Catholic Education supremo-and the specification of Woods's authority was as loose as the word is grandiose. What was sure was that not only did this represent a derogation from Smyth's authority as VicarGeneral, but also that the proposed diminution of the power of the priests over their local schools was highly offensive to many, and intolerable when it turned into no consultation at all.

The structure Woods had devised for the governance of his Catholic education fledgling in South Australia was elaborate enough to carry the weight of civil government for the entire Colony. ${ }^{30}$ Little of it except the Central Council ever took shape, and in effect only the Director-Generalship operated: Woods was the Bishop's sole plenipotentiary in Catholic education.

Woods's vision was of schools suffused with Catholic doctrine and pious practice as their raison d' $\hat{t}$ tre: what later came to be referred to as the 'Catholic atmosphere' proposition. This was possible only in separate Catholic schools. The Australian systems where the state paid virtually all the costs of such schools were disappearing where they had once existed, and had no hope of being introduced in South Australia, and especially not under the sort of clerical control which was Woods's sine qua non.

Accepting that 'going it alone' was all but inevitable, Woods turned his attention to establishing a new authority by destroying old accommodations and usages. He used his new power to dismiss as incompetent three female teachers in existing Catholic schools, loftily advising them to re-apply after spending a period as pupil teachers to the Sisters of St. Joseph. He concerned himself not at

29. Foale 1989, p. 19. Woods to MacKillop.

30. Cf. Murphy's earlier sardonic comment on the administrative prowess of the Sacred Congregation of Propaganda Fide: 'We have three bishops in Western Australia, sufficient to convert the entire colony, black and white.' Condon 1994b: Murphy to Goold, 9 Mar. 1850. 
all with the fact that the Institute did not yet exist, and that the little band of aspirants to sisterhood had no obvious superiority in education, training, and experience-even in religious preparation-over the dismissed laywomen. The dismissals were symbolic of a new power being built; to the non-symbolic need of these women for subsistence in the interim, Woods gave no thought.

Woods continued the slashing and burning on a larger front: he informed the Central Board of Education that at least four of its schools were de facto Catholic, complete with teaching the Catholic catechism and reading the Douai Bible during school hours, and that the state inspectors were conniving at this flagrant breach of regulations. The charge of dereliction of duty naturally alienated the inspectors and the Board. ${ }^{31}$

All this-and more-had occurred within two months of Woods's moving to Adelaide, and before Mary MacKillop arrived to formally begin the Institute. Feelings were high when MacKillop and Rose Cunningham arrived in Adelaide on 23 June, being immediately joined by Ellen McMullen. They began teaching in the Cathedral School on 2 July, the first two in their new religious habits as Sisters. Their reception was not so much critical as watchful, but the school was soon thriving, and the Institute itself even more so: the ten members at the end of the first year, 1867, had grown to 111 at the end of $1870 .^{32}$

The Institute's growth brought its own problems, however. Having created the demand, in a sense, Woods was keen to fill it and Mary MacKillop thought it her duty to comply. A flood of requests for Sisters to staff Catholic schools was rather too willingly met, at the expense of education, training, and religious formation. ${ }^{33}$

What came more and more into question was the innovation which the Institute represented. The older style of religious order was increasingly being supplanted by the newer Institutes by the mid-nineteenth century: the old static and secluded monasteries and convents were replaced by Institutes working more in the world, rather than within the confines of the convent/monastery (e.g., Cornelia Connelly, below). The trend was not immediately obvious, and was not noticed at all in Adelaide, where there had never been any religious houses and where there was little knowledge of religious orders even of the old type. Even the priests and those few laity who had had any prior experience of religious communities could only have known the old model-Orders like the Sisters of Mercy.

The new sisters, however, were very visible: they wore their religious habits in the street; they travelled around-in pairs or sometimes even alone; they lived in small communities in ordinary houses in working-class areas. As South

31. Foale 1989, p. 25.

32. Foale 1989: App. xxv, p. 234.

33. Condon 1994a: Tappeiner to Father General, 30 Oct. 1872. 
Australia's first specimens from a religious order they were an object of lively curiosity.

The Josephite habit was very similar to that worn by the Melbourne Mercy sisters-not surprisingly, since this was the only female religious habit Mary MacKillop and Josephine McMullen had seen anything of. But this sisterhood of St. Joseph had none of the familiar marks of the old Orders: the single prominent Convent in one place, self-supporting from work and invested income, essentially autonomous under the Bishop, permanent, and ideally with chapel and chaplain, sending out a band to another locality to clone the original foundation and be essentially independent of it. ${ }^{34}$

But while even all but the most hidebound were prepared to envisage adaptation to colonial conditions, the extent of the difference was to provide many sticking points. To meet colonial conditions required a mobility which the old fixed foundation could never provide. If the Institute's pre-eminent aim of providing education to all Catholic working-class children were to be met, then a multitude of small schools would have to be provided and a moving frontier followed. A consequence of geography was that the groups of Sisters would be small, often only two, and sometimes moving to follow the population, as in railway-building and on new agricultural frontiers. It followed that many of these Sisters had to work in areas where they might see a priest infrequently -in several early instances, not for six months at a time; a very different worshipping community from the older pattern with chapel and resident chaplain and stately recitation of the Latin Hours in choir.

'No fine ladyism there' is fairly apt. In fact, it serves to introduce a first source of major discord. Both MacKillop and Woods espoused the practice of poverty to a point where virtue became vice. The rejection of government aid for the Sisters' schools served important ideological purposes; the original suggestion of rejection of ownership of land and income-generating assets, on the other hand, would have guaranteed the Order's early self-extinction, and Rome firmly debarred it. ${ }^{35}$ The successful insistence on the rejection of any requirement that intending Sisters provide a dowry, which older Orders used as a source of capital formation, ${ }^{36}$ signalled a necessary major difference from these older Orders. If the Institute of the Sisters of St. Joseph of the Sacred Heart were to live among the working class and serve the working class, then in its recruitment it had to be open to the working class. As a necessary corollary, its ranks were to be open to those women with not only little or no money to bring, but little or no education: the practical expression of this principle was the Institute's refusal to adopt the distinction established by older Orders between 'lay' sisters (who were domestic

34. Flaxman 1991, 50.

35. Condon 1994b: MacKillop to Adelaide Sisters, 8 July 1873.

36. The principle was not unheard of, having been earlier approved for Cornelia Connelly's new Order mentioned below. 
workers) and 'choir' sisters (who performed the major works of the Order, including the recitation of the Divine Office in choir).

The central goal of the Institute was the 'Catholicity' of the education to be received by the children of the Catholic working class. Notions of promoting children in society were anathema to the stoutly middle-class English gentleman, the persona mostly adopted by Woods, and Mary MacKillop's vision consciously excluded anything beyond the secular basics. Refusal to teach music and drawing was for long a talisman cherished by MacKillop, an earnest that a plain and basic education for the working class was all that should be aspired to by the Instituteand its clients, perforce. The achievement of the same goal might have been protected in different ways, nonetheless. And Bishop Sheil captiously turned against them one of the elements of this stand when he objected that the Sisters' pupils sang too much: this was 'Methodistical,' his friends had told him.

What was more serious was that the Sisters were touted as the only proper replacement for all existing Catholic schools conducted by lay people. Yet these schools had to compete in curriculum with the government's Central Board of Education schools, and both sometimes offered 'the higher branches' to meet local demand. The MacKillop and Woods curriculum could not answer such needs, and priests in districts where such schools were functioning successfully were understandably resentful of Woods, his ukase against their schools-and of his innocent accomplices, the hapless Sisters of St. Joseph.

In accounting for the early difficulties, especially in the earliest days, when constant emergencies were so often accepted simply as opportunities, Tappeiner was right to point out that 'the Sisters... were...quickly and imperfectly trained and often sent to schools without having made a novitiate.' Similarly, he was also justified in remarking to the Apostolic Commission that 'the greater number in our schools are infants of about three, four or five years.' He went on: 'For the teaching of these the Sisters are completely suitable. ${ }^{37}$ Certainly, in those class sectors and geographical locations where child labour was an integral part of the domestic economy, schooling was often brief and interrupted. ${ }^{38}$ Tappeiner had greatly elaborated this point in his evidence several months before to the Apostolic Commission. He reported a conversation of 26 August 1871 with the late Bishop Sheil:

[The Bishop] spoke of the Sisters of St. Joseph with great praise, he recounted how much good they did, and he himself refuted with ridicule the objections he had heard, namely that the Sisters were not sufficiently educated. I well remember his words: 'Whenever I visit the schools, especially outside the City, I find that more than half the children can recite only the $\mathrm{ABC}$ and the Lord's Prayer, and certainly for these great

37. Condon 1994a: Tappeiner to Father General, 30 Oct. 1872.

38. Condon 1994b: Ryan to Geoghegan, 25 Apr. 1862; 27 Mar. 1863. 
learning is not required.' I replied, 'It has always been my opinion, too, that if there is in the school one Sister who is sufficiently instructed, apart from the others, that would suffice for the children,' and many other things of this kind, to all of which he completely consented, nor did he utter a word which would express doubt or the least suspicion that the Sisters were useless or lazy, as he was reported to have said very shortly afterwards. ${ }^{39}$

In thus quoting from the Apostolic Commission of 1872 we have got somewhat ahead of ourselves-and of the complications.

During the first absence of Bishop Sheil, Vicar-General Smyth tried to temper the enthusiasms of Woods; the Sisters of St. Joseph grew in numbers and acquired a new city Convent; priestly dissatisfaction with the high-handedness of Woods grew, however, fuelled by some unfortunately rapid and unannounced transfers of Sisters. The Sisters acquired new charitable works and began begging in the streets for sustenance-quite successfully, a rather bemused Protestant middle class being very accepting, supportive, and generous. A new Australian religious order was winning acceptance in a colony which was notable not for the high proportion of poverty amongst its working-class Irish immigrants, which was standard for Australia, nor for the proportion of Catholics in the general population, which was low, nor for the proportion of Catholic clergy who were Irish, which was comparatively low.

On 8 December 1868 the Bishop returned, and relativities and understandings changed. The Bishop brought with him the new foundation of nuns of the 'old' type, already mentioned: the Irish Dominicans from Dublin's Cabra Convent, dedicated, it would seem, to the education of anyone other than the working class. All honour to the Bishop, who had succeeded in getting a foundation from Europe where all his predecessors had failed. All honour, too, to the Sisters of St. Joseph, who yielded to the Bishop's later request that they give their convent to the new arrivals, Mary MacKillop even saying 'it was too grand for us.' Honour, too, to the Bishop for introducing badly needed additions of priests to the diocese, including a Capuchin and two of the Bishop's confreres in the Franciscan Order (Horan and Keating). He took pleasure in reporting that-without his asking - they wore their habits in church. ${ }^{40}$

Impelled by his 'friends,' the Bishop embargoed public begging by the Sisters of St Joseph. Impelled by reality (i.e., paying to support the Sisters in their various works), he condescended to allow the Josephites to resume begging.

The rapid expansion of the Josephite Order and the number of schools it conducted put great burdens of management on MacKillop, and entailed almost constant travel. The need for constant personal supervision also vindicated the

39. Condon 1994a: Tappeiner in evidence to the Apostolic Commission, 11 June 1872.

40. Condon 1994b: Sheil to Reville, 3 Mar. 1869. 
other cardinal principle of the Rule approved by Bishop Sheil: that the sisters were to have a centralized system of government, rather than leave new foundations to be directed by a local superior under the general guidance of the Bishop of the diocese, as the older type of Order tended to do. Woods's high-handedness continued to rankle, and there was a tendency for MacKillop to transfer Sisters fairly frequently - usually for good reasons, which won assent from the local priests when they were consulted, though they often were not.

While the Bishop was in the diocese he supported Woods and the Sisters. However, he was off again to Rome for the First Vatican Council within ten months (October 1869), not to return for fifteen months (1 February 1871).

His doubling of the number of priests and the introduction of the Dominican sisters caused a decided rupture with the old ways. Adelaide had not been typical of Australian dioceses, in that the Irish clergy did not dominate numerically in the foundation years. But a 50-50 ratio of Irish to non-Irish clergy in 1864 became by 1871 almost a two-to-one ratio in favour of the Irish. ${ }^{41}$

The Irish newcomers understandably tended to associate with each other. The leader of the group was undoubtedly the young Charles Horan. A Franciscan like Sheil, he had been recruited in Ireland with a fellow friar, Patrick Keating, and they had travelled to Adelaide on the same ship as the Dominican nuns and the Bishop. Horan was appointed to the Kapunda district, with Keating as his assistant. Before long, the local Sisters of St. Joseph heard persistent complaints about Keating's behaviour in the confessional and reported them to Woods, who notified Smyth, the Vicar-General. Smyth investigated, and immediately dismissed Keating for the alleged improprieties: over-familiarity in the confessional, or perhaps 'taking liberties'; what we would no doubt today call some form of minor sexual harassment. Smyth would have dismissed Horan as well for turning a blind eye to the matter, but feared the Bishop's displeasure. Horan heard how the account had reached the Vicar-General, and vowed to destroy Woods and the Sisters.

Woods played into Horan's hands. Woods was betrayed by his own arrogance and credulity in matters related to mysticism - unusual in one whose name is still mentioned with respect in the history of world geology. ${ }^{42}$ Several of the young Sisters of St. Joseph-the ecstatics, they were later called-fraudulently professed to have had mystical experiences: apparitions of the Virgin, stigmata, forcible removal by Old Nick himself, etc. Where every other cleric agreed with Tappeiner ('Before making the leap of faith, first exhaust the natural explanations' was his general principle), ${ }^{43}$ Woods was a believer (fervent, and deceived), flattered at marks of God's presence in his immediate world.

41. Foale 1989: App. DX, p. 216.

42. E.g., a paper on Woods's geological work in Japan was given to the Royal Society in Adelaide in 1993.

43. Condon 1994a: Tappeiner to Father General, 30 Oct. 1872: '...nothing other than 
Woods saw that the visionaries were rewarded with not only special marks of esteem, but power: the seventeen-year-old Sister Angela, for instance, was named Mistress of Novices. Worse, since he knew that Mary MacKillop did not share his enthusiasm for the alleged visionaries, he seemed not to mind that she was often out of Adelaide on visitations to convents. Unfortunately-in many ways-for the Institute, Bishops Matthew Quinn of Bathurst and James Quinn of Brisbane requested foundations at this time. MacKillop led foundation parties and stayed away for lengthy periods; on her part, she thought it her duty to go, whatever her unease about events in Adelaide.

The press had begun to take an active interest in Catholic affairs and the ordinary secular press loved nothing so well as a sensation, for example the trumped-up 'Convent Case' of September 1868, publicized in March 1869, which was Maria Monk writ small. The press even got wind of one of the excesses of the ecstatics: the removal of the Blessed Sacrament from the Chapel of the Mother House of the Sisters of St. Joseph. A heinous crime under Canon Law. But Vicar-General Smyth temporized in this delicate and potentially explosive matter, as he had so often been forced to do in previous years by the ambiguity of his authority.

On 30 June 1870 Vicar-General Smyth's administrative problems were resolved for him by a fatal stroke. Authority in the diocese crumbled. In the Bishop's absence, Archbishop Polding appointed the most senior priest, Russell, as Administrator until the Bishop could make his own nomination. ${ }^{44}$ Two months later Sheil complicated matters further by refusing to leave Russell alone in authority but naming instead Woods, Reynolds, and Byrne to join him. In the interests of effective government they all deferred to Russell-except that Woods surrendered none of his total control of education.

The Bishop finally returned to Adelaide on 1 February 1871 . He was fatally impaired in mind and body, but nonetheless began to lay about him. He was confronted immediately on his return with a petition from most of the senior priests, all united in their wish to see Woods removed from power over the Sisters of St. Joseph, and over Catholic education generally. Bishop Sheil's response was a thundering Pastoral Letter rebutting the objections raised to the Sisters (the last good thing he was to say about them in public), and threatening heavy spiritual sanctions against Catholics who supported government schools. The Bishop did not appoint a new Vicar-General. He wished to appoint Horan, who became his constant companion and whom he thought of as his successor, but even Sheil acknowledged that Horan was so junior that it was a political impossibility. ${ }^{45}$

the natural effects of the conjuncture of a vivid imagination with a nervous disposition.'

44. Condon 1994b: Polding to Russell, telegram of 13 July 1870.

45. Condon 1994a: Tappeiner to Father General, 18 Jan. 1873. 
Having fanned the flames of the general dissatisfaction with Woods and his direction of the Sisters of St. Joseph, the Bishop proceeded to light the fires of militant nationalism by giving blatant preference to his Irish priests. Not without contestation, of course, some of it ironic: on being told that he had lost his mission district because he was not Irish, one of the Jesuits observed that, for him as a native German, this was a fault which would be difficult to remedy. ${ }^{46}$

Tappeiner heavily criticizes Sheil's administration as 'spiritless' right from the beginning, and stops just short of a charge of downright negligent indolence. ${ }^{47}$ The Bishop by this point was under great pressure from all sides and in no condition to withstand it. He was a creature of the Horan faction.

Russell was soon dismissed, but Woods was always the major target. Woods's decline was swift. He moved from the privileged billet of the Bishop's House in March 1871, and was soon stricken with an illness that for a while appeared fatal. On his recovery, however, Mary MacKillop persuaded Woods to make a clean breast to the Bishop about the $£ 4,000$ worth of debt he had incurred. ${ }^{48}$ Sheil refused to acknowledge it as a diocesan debt, no doubt haunted by awareness of the other debt of $£ 8,000$ with which his own travels and extravagances had saddled the diocese. ${ }^{49}$ On 1 August 1871 Woods left Adelaide, never to hold priestly office there again nor, effectively, to exercise direction of the Sisters of St. Joseph; from this post he was before long removed by Rome, on the advice of the Apostolic Commission. ${ }^{50}$

The removal of Woods would have satisfied most of the 'old hands' faction led by Reynolds. The Horan faction was clearly intent on fatally abridging the independence of the Institute as well. They represented this to Sheil as a way to save face, preserve Catholic education, and conserve money. Their essential prescription was to abolish central government and make each house of Sisters subject to the authority of the local priest. Sheil was active in the three weeks before 22 September 1871 , visiting convents with a zeal never previously seen in him. He issued nothing but harsh and diffuse criticism and threatened sweeping changes to the essentials of the Rule, though never systematically and never in writing. When a Sister pressed him on one occasion to do so he replied, 'I will not gratify a mere female whim. ${ }^{51}$ In brief, all that was innovative and distinctive about this new Australian Order-as outlined above-was to be abandoned in favour of a crippled and unworkable version of the old Orders: politically, it marked the roaring return of hierarchy, patriarchy, and class division.

46. Foale 1989 , p. 84.

47. Condon 1994a: Tappeiner to Father General, 18 Jan. 1873.

48. Foale 1989: MacKillop to Woods, 20 June 1871.

49. Condon 1994a: Tappeiner to Father General, 18 Jan. 1873.

50. Condon 1994a: Submission to the General Congress, Apr. 1873.

51. Condon 1994a: Apostolic Commission, evidence of Sisters Teresa and Monica. 
There was even an Inquisition of sorts. Frs. Horan and Murphy came to the Convent to ascertain the Sisters' fitness to teach, in preparation for their division into Choir Sisters, Lay Sisters-and disposables! For fitness to teach, they examined the Sisters who did domestic duties rather than those who taught, in the process behaving arrogantly and even bumptiously-for example, insisting on going to a dormitory to verify that a Sister was indeed sick, rather than taking the Sister Superior's word. ${ }^{52}$

Matters came to a head on 21 September 1871, when Sheil announced that all MacKillop's authority had ceased, appointed a new superior of the house, ordered the Sisters to assemble next day, and commanded Mary MacKillop to go immediately that day to Bagot's Gap, a small town some fifty miles away. Not receiving that message until her return to the Convent that evening, too late to comply, MacKillop sought to see the Bishop for clarification and to discuss the request for a new foundation in Bathurst. She saw only Horan, who reiterated the Bishop's command and then said, 'As I understand it, you are not going to St. John's tomorrow?' Mary MacKillop replied:

'Father, how can I, under that [new] Rule?' I spoke with deliberation because I feared to refuse, nor was I willing to give the Sisters any reason to think that I accepted the new Rule. ${ }^{53}$

Next day (22 September 1871) the Bishop came to the Convent, summoned her from her sickbed, accused her of 'disobedience and rebellion,' and excommunicated her ritually with bell, book, and candle (actually, with mitre and crozier).

Uproar, indignation, and confusion reigned in the next few weeks. By the Bishop's command, all the nuns left the Franklin Street convent the next day; most re-formed as a congregation in another house under the old Rule, with a Superior but without their religious habits. Mary MacKillop herself did not join them-one of Sheil's strictures promised excommunication to anyone who so much as talked to her. Oddly, the country Sisters were left to continue undisturbed, and the Sisters in special charitable works like the Refuge and the Solitude were specifically asked to carry on as normal.

This final cataclysmic evidence of what presented itself as episcopal hubris brought dissent to a head. Ignoring the faults in the administration of the Adelaide diocese was no longer an option after the violence enshrined in the choice of excommunication as a sanction. A new and articulate laity was forming in South Australia, and had just founded a newspaper, The Irish Harp. It immediately confronted the Bishop, beginning with a challenge-well grounded in Canon

52. Condon 1994a: Evidence in Report to the General Congress.

53. Condon 1994a: Evidence of Mary MacKillop to the Apostolic Commission, Supplementary Statement. 
Law-to the validity of the excommunication, concluding that the Bishop had committed a serious sin, and that Mary MacKillop was entirely guiltless.

Two consecutive issues of the paper were enough to force the Bishop to stop further harassment of the Sisters. By this time his health and intellect were rapidly failing. By the end of December he had retired to the country district of Willunga in a vain attempt to restore his health. Whilst there, representatives of the factions closely attended him day and night, the Horan faction plying him with mulled wine (semper offerens nonnihil vini cremati aqua mixti) to the point where he was mostly torpid. ${ }^{54}$ Before his death on 1 March 1873 , however, he lifted his excommunication of Mary MacKillop and named Reynolds to be Administrator.

Even before the Bishop was cold in his grave, the Horan faction defied the Administrator's authority by publicly traducing him and the Sisters of St. Joseph. The culmination of the campaign was a lurid libel on the Sisters which was printed in the Protestant Advocate. It was typical of the sort of propaganda run episodically in various English newspapers over the previous twenty-five years-the Maria Monk style we mentioned above - but if anything more sweeping: not only were the convents bordellos, with nuns and female pupils as sex slaves to the priesthood, there were scenes of every imaginable depravity and vice-including, naturally, infanticide.

Reynolds and J.D. Woods (father of one of the Sisters of St. Joseph, and brother to Tenison Woods) brought a defamation suit against the editor, who was convicted, fined, and sentenced to six months' jail. The trial began just as the two Bishops who formed the Apostolic Commission to enquire into the Adelaide diocese arrived. The Bishops publicly endorsed Reynolds's authority, and praised the restored Sisters of St. Joseph. Their report added a condemnation of the faction led by Horan and recommended his recall to Ireland, which was done. With unusual speed, Rome appointed Reynolds Bishop of Adelaide.

It would be pleasant to report that this was the end of Mary MacKillop's trouble with bishops. Nothing could be further from the truth, however. And the explanation lies, as I have indicated, not in any 'Bishops are bastards' theory, or unflattering deductions about Mary MacKillop's personality —or about her sanctity, either. It lies in the coincidence of a strong push for innovation which challenged a disorganized and dispersed authority.

SEVERAL COMPARATIVE case studies from around this time are available. The papers of Cardinal Cullen of Dublin provide the case of the Sisters of Mercy Convent at New Ross in 1877-78. All the sensational elements we have heard of above are present: faction in the Convent; a mad sister with visions and ecstasies; stigmata; the priest who slept with a Sister or Sisters in the Convent, etc. The

54. Condon 1994a: Tappeiner to Father General, 18 Jan. 1873. A large slug of brandy is usually added to mulled wine. 
Bishop, who had lost control, was eventually able to restore order with the help of nuns from an affiliated convent and the special authority wielded by Cullen. ${ }^{55}$

The second case is that of Mother Cornelia Connelly (1809-79), founder of the Society of the Holy Child Jesus. Her life and work were much more varied and noteworthy - not to say more sensational - than those of Mary MacKillop. But each achieved the foundation of an innovative religious Order meeting new needs and working much more in the world. In these Orders women provided their own governance and administration emanating from a central authority. This 'central government' by a Superior-General was a major stumbling block to bishops, who much preferred the older pattern which left individual convents autonomous of any centralized control by the Order, and subject finally to the authority of the local bishop.

Cornelia Connelly was an American, who married an Episcopalian minister and had five children, two of whom died in infancy. She and her husband converted to Catholicism, and he formed the further project of becoming a Catholic priest, and a Jesuit at that! She did not wish to prevent him, and eventually wished to join a religious Order herself. Having some money to support the family - and good entrée - they went to Rome to plead their cases in person. The price of the ordination of Cornelia's husband was a formal, written vow of chastity. They then went their separate ways. He was eventually ordained and he and Cornelia both ended up in England. Cornelia was encouraged and sponsored there by Bishop (later Cardinal) Wiseman to found her Order, the Society of the Holy Child Jesus.

Her husband, however, soon renounced both priesthood and Catholicism and turned up at her convent's gate demanding a restoration of conjugal rights. Some newspapers, of course, regaled the public with highly coloured anti-convent stories. He eventually sued for his rights and won, but the decision was suspended by the Court of Appeal.

Called 'that bold woman ${ }^{, 56}$ at a time when no compliment was intended, Cornelia Connelly was more often obstructed by bishops than helped. The principal bone of contention was always central government and the degree of autonomy from bishops which it conferred. Unlike Mary MacKillop, Cornelia Connelly did not live to see Rome give full acceptance to her Rule enshrining central government.

One example of her style must suffice. Her Bishop, Dr. Grant, was a scholar and canonist but suffered from "extreme vacillation of mind. ${ }^{57}$ He got into a lather about the impending visit of a Drawing Inspector who was a Protestant. To his first enquiry Mother Connelly replied:

55. Dublin Diocesan Archives, Cullen Papers, Nuns, 1877-78, File V, Section 329/1: Bishop Warren and New Ross Convent.

56. Flaxman 1991, p. 272.

57. Flaxman 1991, p. 234. Echoes of Sheil? 
Yes, we have received notice that the Drawing Inspector is to come on the 17th but we do not know that he is a Catholic, and if he is not he will of course have his journey for nothing. What shall we say to him? Sir, are you a Catholic? 'Yes madam but not a Roman Catholic.' Sir, I am sorry you have had the trouble of this long journey, but you will have to be approved by the Bishops' Poor School Committee before we can admit you into our schools. Will this do, My Lord? It seems to me very uncivil.

The Inspector was admitted, as one might have surmised. Bishop Grant replied to her report of the first round of inspection, concerned that the Inspector had obviously spoken to the pupils. A week later she gave him his congé:

I think it would be very unreasonable to complain of the Inspector's speaking to our girls, and I could not dream of doing such a thing. 58

It may well be that Cornelia Connelly's forthrightness was unpalatable to bishops, but it does not explain the repeated attempts by three of them ${ }^{59}$ to make the Order a diocesan one, not one centrally governed by a Superior-General, and to change its character fundamentally, for example in the matter of poverty, by including acceptance of a dowry.

All this very closely parallels the experience of Mary MacKillop in dealing with bishops. The Bishops of Bathurst and Brisbane, who had early clamoured for foundations of Sisters of St. Joseph, reneged on the issue of central government. Her early protector, Reynolds of Adelaide, eventually turned against her as well on this issue, and she was forced to move the Mother House and Novitiate to Sydney. Her own continuing leadership of the Institute was blocked by Rome, and she was returned to its leadership fortuitously. And all this was visited upon a person who was universally known for her respect for bishops and clergy and her total unwillingness even to hear them criticized in her presence. Certainly in none of her letters can we see any of the asperity which occasionally breaks out in Cornelia Connelly's correspondence.

Yet this alone cannot explain why the campaign for Cornelia Connelly's canonization appears to be languishing. Some of the reason must surely lie in the fact that Cornelia Connelly's cause is promoted by only one Order and some of the English bishops, whereas that of Mary MacKillop is being advanced as virtually a national issue for Australians, and with the total and active support of the Australian Catholic hierarchy. If she remains concerned about such things, she might be excused for thinking of this as the last miracle in the process.

58. Flaxman 1991, p. 283.

59. See Flaxman 1991, p. 340, Bishop Danell. 


\section{Works Consulted:}

Burley, Stephanie. 1992. 'None more anonymous? Catholic teaching nuns, their secondary schools and students in South Australia, 1880-1925.' Unpublished M.Ed. thesis, University of Adelaide.

Condon, Brian, ed. 1993a. The Journal of James Alipius Goold, first Catholic Bishop and Archbishop of Melbourne, 1848-1886. Final typescript version. Microfiche edition to follow.

1993b. Letters of Bishop J.P. Hynes to his nephew J A. Goold, first Catholic Bishop and Archbishop of Melbourne, 1844-1886. Final typescript version. Microfiche edition to follow.

-----. 1994a. The Apostolic Commission to Adelaide, 1873: Reports, evidence and related correspondence, 1868-1874. Final typescript version. Microfiche edition to follow.

----. 1994b. Letters and documents supporting historical studies of the Catholic Church in Australia. Final typescript version of expanded and revised edition. (First published 1984.) Microfiche edition to follow.

Flaxman, Radegunde. 1991. A woman styled bold: the life of Cornelia Connelly. London; Darton Longman \& Todd.

Foale, Marie J. 1989. The Josephite story. The Sisters of St. Joseph: their foundation and early history, 1866-1893. Sydney; St. Joseph's Generalate.

Modystack, William. 1982. Mary MacKillop: a woman before her time. Adelaide: Rigby.

Press, Margaret M. 1986. From our broken toil: South Australian Catholics, 1836-1906. Adelaide: Archdiocese of Adelaide.

Stanford, Peter. 1991. 'Nun the wiser.' Review of Flaxman (1991) in The Guardian Weekly, 9 June 1991, p. 26.

Thomas, Vincent. 1989. 'The role of the laity in Catholic education in South Australia from 1836 to 1986.' Unpublished Ph.D. thesis, Flinders University.

Thorpe, Osmund. 1957. Mary MacKillop. London: Burns \& Oates. 